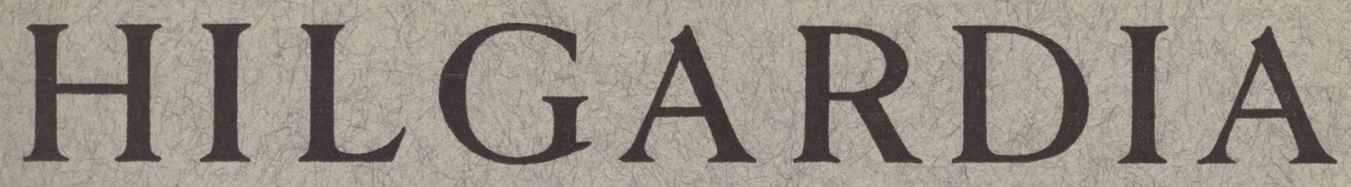

A Journal of Agricultural Science Publisbed by the California Agricultural Experiment Station

\title{
THE VOGES-PROSKAUER
}

REACTION AND DIFFERENTIATION

\section{OF THE \\ COLIFORM BACTERIA}

REESE H. VAUGHN, GEORGE T. WEDDING, AND JOSEPH TABACHNICK 
In order that the information in our publications may be more intelligible it is sometimes necessary to use trade names of products or equipment rather than complicated descriptive or chemical identifications. In so doing it is unavoidable in some cases that similar products which are on the market under other trade names may not be cited. No endorsement of named products is intended nor is criticism implied of similar products which are not mentioned. 


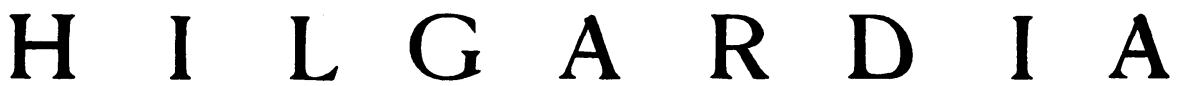

A Journal of Agricultural Science Published by

the California Agricultural Experiment Station

VoL. 18

August, 1948

No. 9

\section{THE VOGES-PROSKAUER REACTION AND DIFFERENTIATION OF'THE COLIFORM BACTERIA ${ }^{1}$}

\author{
REESE H. VAUGHN, ${ }^{2}$ GEORGE T. WEDDING, ${ }^{3}$ \\ and JOSEPH TABACHNICK ${ }^{3}$
}

THE UsE of the coliform bacteria-Escherichia and Aerobacter-as indicators of the sanitary quality of water and other foods, food-production plants, and eating establishments, has been advocated for many years. Furthermore, the importance of these bacteria as agents of spoilage of such dissimilar food products as candy, cheese, cucumber pickles, dehydrated vegetables, maple sirup, olives, and potassium bitartrate (cream of tartar), has been recognized. It has, therefore, become increasingly necessary to distinguish between the two genera of coliform bacteria, especially when confronted with a problem which may involve certain aspects of sanitation as well as spoilation of a food.

Primary differentiation between the genera Escherichia and Aerobacter has been made on the basis of the Voges-Proskauer test, a qualitative measure of acetoin production from glucose. The species of Aerobacter (largely of nonfecal origin) produce acetoin, whereas the species of Escherichia (commonly used as indicators of fecal pollution) do not, under controlled and standardized conditions.

Conflicting data and opinions concerning the Voges-Proskauer reaction and differentiation of the coliform bacteria have gradually accumulated during the past decade. The disagreement has arisen especially with respect to the efficacy of various techniques and reagents for performing the VogesProskauer test; and the effect of such factors as the $\mathrm{pH}$ value of the medium and the concentration of various constituents in the medium on the production of acetoin (acetyl-methyl-carbinol) by coliform bacteria.

This investigation was undertaken to :

1. Evaluate newer techniques for determining the Voges-Proskauer reaction.

2. Ascertain the effect of physical factors, including $\mathrm{pH}$ value of the medium and air supply.

3. Determine the effect of concentration of glucose and other chemicals on the production of positive Voges-Proskauer reactions by coliform bacteria.

\footnotetext{
${ }^{1}$ Received for publication July $2,1947$.

${ }^{2}$ Associate Professor of Food Technology and Associate Bacteriologist in the Experiment Station.

${ }^{3}$ Research Assistant, Division of Food Technology.
} 


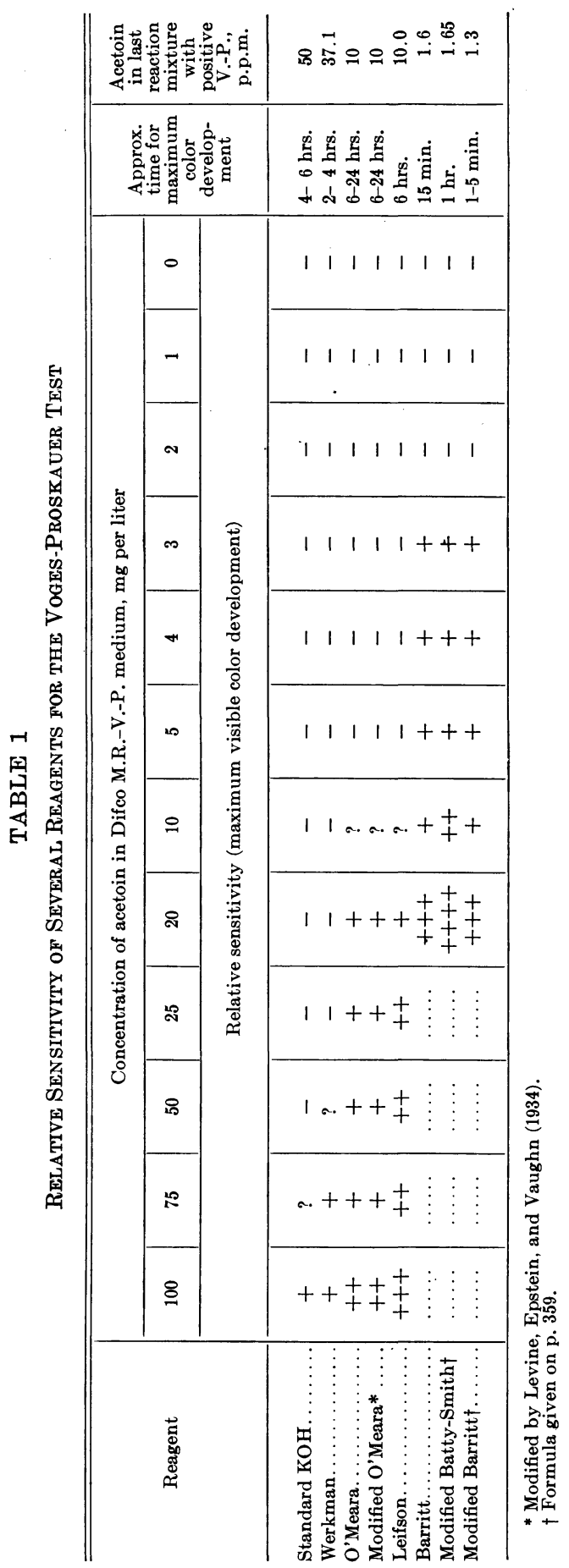




\section{REAGENTS FOR DETERMINING THE PRESENCE OF ACETOIN}

Criteria for any efficient, routine Voges-Proskauer test require that it be sensitive, simple to prepare, easy to use, and rapid in action. All attempts to modify the original Voges and Proskauer test have striven to meet these requirements. Nevertheless, divergence of opinion concerning the merits of various modifications of the Voges-Proskauer test still persists.

Therefore, a study was made of the relative sensitivity and rate of reaction of several reagents used for the Voges-Proskauer test. These included two new reagent mixtures-modifications of the Batty-Smith and the Barritt reagents ; their composition is as follows :

Modified Batty-Smith reagent: $3 \mathrm{ml}$ of 5 per cent a-naphthol in absolute alcohol, $0.1 \mathrm{ml}$ of 2 per cent $\mathrm{FeCl}_{3} \cdot 6 \mathrm{H}_{2} \mathrm{O}$, and $1 \mathrm{ml}$ of 40 per cent $\mathrm{KOH}$ containing 0.25 per cent creatine; used with $5 \mathrm{ml}$ of test solution.

Modified Barritt reagent: $1.3 \mathrm{ml}$ of a-naphthol-creatine- $\mathrm{KOH}$ solution containing 10 parts of 5 per cent $a$-naphthol in absolute alcohol and 3 parts of 40 per cent KOH containing 2.5 per cent creatine; used with $1 \mathrm{ml}$ of test solution.

The relative sensitivity of the reagents was determined by testing them with redistilled acetoin contained in Difco methyl red-Voges-Proskauer medium. Observations on the eight reagents are shown in table 1.

When sensitivity alone is considered, there is evidently little choice between the Barritt (1936) test and the modifications of the Batty-Smith (1941) and Barritt tests made by the present authors. If, however, the approximate times for maximum color development are compared, the modified Barritt test is seen to be significantly better.

It is obvious that the earlier modifications are of poorer sensitivity and slower to react. Although the Leifson (1932) reagent is more sensitive than the Werkman (1930), or standard KOH reagents (American Public Health Association, 1936), the Biuret reactions which result from its use tend to obscure positive tests for acetoin.

The use of ferric chloride, either dropwise or in accurately measured amounts, also tends to obscure positive tests for acetoin. This objection is particularly valid in cases where the concentration of acetoin is barely within the limits of sensitivity of the Voges-Proskauer reagent used for its detection.

A comparison of the reaction time of the Barritt, modified Barritt, and modified Batty-Smith reagents with standard KOH and the modified O'Meara (Levine, Epstein, and Vaughn, 1934) reagent, when used to detect the production of acetoin by Aerobacter cultures, is shown in table 2.

The desirability of the reagents using $a$-naphthol (Barritt, modified Barritt, and modified Batty-Smith) is obvious. However, of the three, the modified Barritt reagent is believed to be the best. The rate of color development is consistently rapid and reaches maximum visual intensity within 1 to 5 minutes. Only one reagent is added to the culture; this fact is distinctly advantageous when many tests must be made. Furthermore, the reagent mixture is stable enough to be stored for some weeks at $0^{\circ} \mathrm{C}$ without impairing its reactivity, as is shown in table 3 .

\footnotetext{
"See "Literature Cited" for citations, referred to in the text by author and date.
} 
Since, however, the reagent mixture does deteriorate on storage, even at $0^{\circ}$ $\mathrm{C}$, the $a$-naphthol and creatine-KOH solutions may be stored separately and mixed just before use. The alcoholic $a$-naphthol will keep for at least 2 months if stored in a tightly stoppered flask in the refrigerator, at $0^{\circ}$ to $10^{\circ}$. Despite

TABLE 2

Comparison of Reaction Time of Several Reagents for the Voges-Proskauer Tests

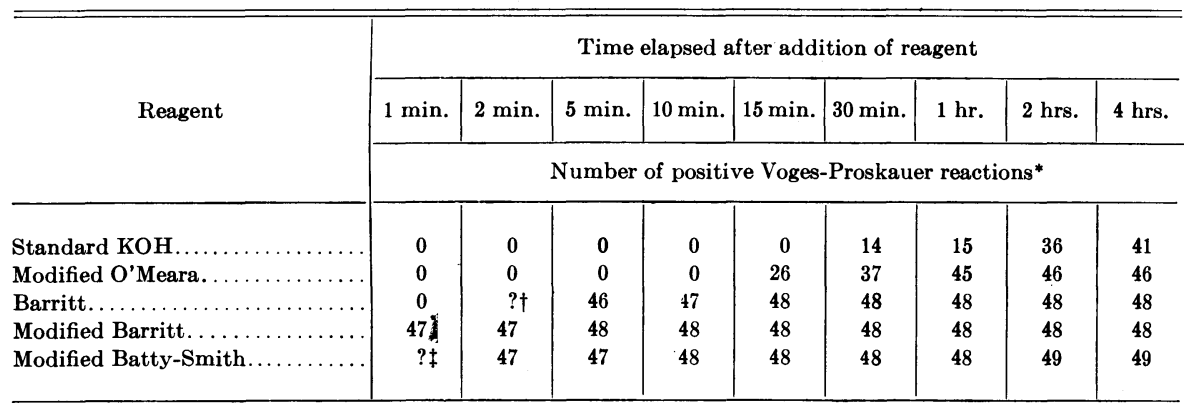

* 50 cultures, including 25 strains each of Aerobacter aerogenes and A. cloacae, grown in Difco M.R.-V.-P. medium for one day at $30^{\circ} \mathrm{C}$ were used for the tests.

+ Color not intense enough to warrant differentiation between positive and negative reactions.

$\ddagger$ Presence of iron chloride causes formation of yellow color complex which interferes with detection of pink color indicative of starting positive V.-P. reaction.

TABLE 3

EfFect of Temperature and Storage Period of $a$-Naphthol-Creatine-Alkali Solution on V.-P. REAction*

\begin{tabular}{|c|c|c|c|c|}
\hline \multirow{3}{*}{ Storage period, days } & \multicolumn{4}{|c|}{ Storage temperature } \\
\hline & $0^{\circ} \mathrm{C}$ & $25^{\circ} \mathrm{C}$ & $37^{\circ} \mathrm{C}$ & $55^{\circ} \mathrm{C}$ \\
\hline & \multicolumn{4}{|c|}{ Relative intensity of V.-P. reaction (10-minute reading $) \dagger$} \\
\hline $2 \ldots \ldots$ & $+++t$ & $+++t$ & $++t+$ & $+1+T+$ \\
\hline$[3 \ldots \ldots \ldots$ & $++t+$ & ++++ & ++++ & $++t+$ \\
\hline $4 \ldots \ldots \ldots$ & ++++ & $+t+8$ & $+++a$ & $\pm^{8}$ \\
\hline $7 \ldots \ldots \ldots$ & $+++t$ & $++a$ & ?a & $-\mathbf{a}$ \\
\hline $21 \ldots \ldots \ldots$ & $+t+t$ & ++8 & $? \mathrm{~s}$ & - \\
\hline $49 \ldots \ldots \ldots \ldots \ldots \ldots \ldots \ldots \ldots \ldots$ & $+++t$ & $\rightarrow$ & ? & - \\
\hline 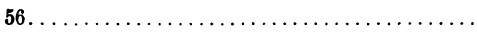 & $++t+$ & $-\mathbf{a}$ & ?a & - \\
\hline
\end{tabular}

* Test culture was Aerobacter cloacae grown in Difco M.R.-V.-P. medium for 1 day at $30^{\circ}$ C.

+ The reagent was prepared by mixing 3 parts of creatine-KOH solution with 10 parts of a-naphthol solution. The $a$-naphthol solution contained 5 grams of $a$-naphthol made to $100 \mathrm{ml}$ with absolute ethyl alcohol. The creatineKOH solution contained 2.5 grams of creatine in $100 \mathrm{ml}$ of 40 per cent KOH. The reagent was used in the proportion of $1.3 \mathrm{ml}$ of reagent to each $\mathrm{ml}$ of culture.

a The V.-P. reaction was ++++ positive after 30 minutes.

previous criticisms of the keeping quality of creatine- $\mathrm{KOH}$ solutions, they remain stable for at least a month if stored under refrigeration at $0^{\circ}$ to $10^{\circ}$.

The creatine- $\mathrm{KOH}$ solution especially is to be recommended. It affords the only means of accurate control of creatine added to the reaction mixture and 
besides saves time and creatine. The modified Barritt and Batty-Smith reagents need only $8 \mathrm{mg}$ of creatine per test as compared with the "knife-point" (approximately $25 \mathrm{mg}$ ) of creatine recommended for the original reagents.

On the basis of these results and considerable use in the laboratory, it is believed that the modification of the Barritt reagent made by the authors most nearly meets all requirements for an ideal Voges-Proskauer reagent for routine use. The sensitivity is equal to any Voges-Proskauer reagent now commonly used for detecting acetoin production by bacteria, and the reaction is faster. It is simple to prepare, and easier to use because only one solution is needed. It contains no chemical which tends to obscure a positive test.

TABLE 4

Efrect of Phosphate Buffers of Different pH Values on the V.-P. Reaction

\begin{tabular}{|c|c|c|c|c|c|c|c|c|}
\hline \multirow{3}{*}{ Test organism } & \multicolumn{2}{|c|}{$\mathrm{pH} 6.85^{*}$} & \multicolumn{2}{|c|}{$\mathrm{pH} 7.20^{*}$} & \multicolumn{2}{|c|}{ pH 7.48* } & \multicolumn{2}{|c|}{ pH 7.89* } \\
\hline & 2 days $\dagger$ & 4 days $\dagger$ & 2 days $\dagger$ & 4 days & 2 days $\dagger$ & 4 days $\dagger$ & 2 days $\dagger$ & 4 days $\dagger$ \\
\hline & \multicolumn{8}{|c|}{ Number of positive V.-P. reactions $\ddagger$} \\
\hline Aerobacter aerogenes (25 cultures) $\S$. & 21 & 23 & 11 & 11 & 0 & 0 & 0 & 0 \\
\hline A. cloacae (25 cultures)........... & 24 & 24 & 16 & 20 & $\mathbf{0}$ & $\mathbf{0}$ & $\mathbf{0}$ & $\mathbf{0}$ \\
\hline Escherichia spp. (50 cultures)..... & 0 & 0 & 0 & 0 & 0 & 0 & 0 & 0 \\
\hline
\end{tabular}

* Buffered with $0.3 \mathrm{MPO}_{4}$. The basal medium contained 5 grams of glucose and 7 grams of proteose peptone (Difco) per liter.

+ Incubation period at $30^{\circ} \mathrm{C}$.

Modified Barritt reagent.

The Aerobacter cultures all were V.-P. positive in Difco M.R.-V.-P. medium.

\section{THE EFFECT OF $\mathrm{pH}$ OF THE MEDIUM ON THE PRODUCTION OF ACETOIN}

It is apparent from a study of the literature that the $\mathrm{pH}$ (reaction) of the medium must influence the production of acetoin by cultures of Aerobacter although the extent of effect is not clear. The results reported by Mickelson and Werkman (1938) and Banerjea (1944) indicate a definite effect of $\mathrm{pH}$ on production of acetoin by cultures of $A$. aerogenes, although not so striking as those reported by Silverman and Werkman (1941). The latter investigators found that cell-free enzyme prepared from a culture of $A$. aerogenes had a definite optimum $\mathrm{pH}$ range for acetoin production and a $\mathrm{pH}$ value above which its production was suppressed.

A study was made of the effect of $\mathrm{pH}$ on the ability of Aerobacter aerogenes and $A$. cloacae cultures to produce acetoin in media with various $\mathrm{pH}$ values controlled by the use of $0.3 M$ phosphate buffer or $0.1 M$ citric acid plus $0.2 M$ phosphate buffer. Results obtained with phosphate buffers are shown in table 4 . The $\mathrm{pH}$ value of the medium does have a striking effect on the ability of Aerobacter cultures to produce acetoin if the $\mathrm{pH}$ is controlled by buffers so that the intermediate and terminal values are identical or nearly identical to the initial value. Under such conditions it is found that $\mathrm{pH}$ values between 7.2 and 7.3 markedly suppress acetoin production. Similar results were obtained with the citric acid-phosphate buffer. Other buffer systems either were toxic or did not control the $\mathrm{pH}$ of the medium adequately. 
Banerjea (1944) and Smith, Gordon, and Clark (1946) have suggested that phosphate in the medium suppressed the number of positive Voges-Proskauer reactions, althoúgh phosphate as di-basic potassium phosphate is a constituent of the M.R.-V.-P. medium most widely used the world over. Others, including Reynolds and Werkman (1937), Kluyver and Molt (1939), and Sakaguchi and Tada (1940), preferred to control $\mathrm{pH}$ values of their media with carbonate salts. A study was therefore made of the effect of carbonate salts used to control $\mathrm{pH}$, on acetoin production. The results with carbonate salts (calcium, magnesium, and zinc) also show that if the intermediate and terminal $\mathrm{pH}$ values are controlled at or near the initial value, the $\mathrm{pH}$ has an important effect on acetoin production; these results thus confirm the data obtained with phosphate and citric acid and phosphate buffers and again substantiate with growing cultures the observations of Silverman and Werkman (1941) on the effect of $\mathrm{pH}$ on enzymatic acetoin production.

TABLE 5

The Effect of Aerobic and Anaerobic Conditions on Ability of Aerobacter Cultures to Produce Positive V.-P. Reactions

\begin{tabular}{|c|c|c|c|c|c|c|c|c|}
\hline \multirow{3}{*}{ Test organism } & \multicolumn{4}{|c|}{$\begin{array}{l}\text { Aerated culture* } \\
\text { (shaking machine) }\end{array}$} & \multicolumn{4}{|c|}{$\begin{array}{c}\text { Anaerobic culture } \dagger \\
\text { (anaerobic jar with nitrogen gas) }\end{array}$} \\
\hline & \multicolumn{8}{|c|}{ Number of V.-P. positive cultures $\ddagger$} \\
\hline & 1 day & 2 days & 3 days & 4 days & 1 day & 2 days & 3 days & 4 days \\
\hline Aerobacter aerogenes (25 cultures). & 16 & 11 & 7 & 5 & 24 & 24 & 24 & 24 \\
\hline A. cloacae ( 25 cultures).......... & 24 & 24 & 23 & 23 & 24 & 25 & 25 & 25 \\
\hline
\end{tabular}

* $100 \mathrm{ml}$ of Difco M.R.-V.-P. medium in 500-ml Erlenmeyer flask incubated at room temperature $\left(25-30^{\circ} \mathrm{C}\right)$. $\dagger 100 \mathrm{ml}$ of Difco M.R.-V.-P. medium in $200-\mathrm{ml}$ Erlenmeyer flask incubated at room temperature $\left(25-30^{\circ} \mathrm{C}\right)$;

‡ Barritt reagent without creatine.

\section{THE EFFECT OF AIR SUPPLY ON PRODUCTION OF ACETOIN}

When continuous shaking was used to facilitate control of $\mathrm{pH}$ with insoluble carbonate salts it was noted that the resulting aeration suppressed acetoin production by some cultures of Aerobacter aerogenes. Consequently, a more detailed study was made to determine whether the effect noted was the result of aeration or some other factor. Results of one aeration experiment with Difco M.R.-V.-P. medium are shown in table 5.

It has been assumed for some years that aerobic conditions (that is, aeration) favor the production of acetoin by cultures of Aerobacter as claimed by O'Meara (1931), Reynolds and Werkman (1937), Mickelson and Werkman (1938) and others. Nonetheless, it is quite evident that, under the conditions of this experiment at least, aerobic conditions suppressed rather than favored the production of acetoin, particularly by cultures of $A$. aerogenes.

Several characteristic types of cultures were found on the basis of their ability to produce acetoin. These types are shown in table 6 .

Further proof that aeration adversely influenced acetoin production by cultures of Aerobacter was obtained by use of the aeration apparatus shown 
TABLE 6

Reactions of Various Cultures of Aerobacter Species Grown under Aerobic and ANaERobic Conditions

\begin{tabular}{|c|c|c|c|c|c|c|c|c|c|}
\hline \multirow{3}{*}{$\begin{array}{c}\text { Species } \\
\text { and type } \\
\text { designation }\end{array}$} & \multirow{3}{*}{$\begin{array}{c}\text { Number } \\
\text { of } \\
\text { cultures }\end{array}$} & \multicolumn{4}{|c|}{ Aerobic* } & \multicolumn{4}{|c|}{ Anaerobic $\dagger$} \\
\hline & & \multicolumn{8}{|c|}{ V.-P. reaction $\ddagger$ after incubation at room temperature for } \\
\hline & & 1 day & 2 days & 3 days & 4 days & 1 day & 2 days & 3 days & 4 days \\
\hline \multicolumn{10}{|l|}{$\begin{array}{l}\text { Aerobacter aero- } \\
\text { genes: }\end{array}$} \\
\hline Type A...... & 8 & - & - & - & - & ++++ & ++++ & ++++ & ++++ \\
\hline Type B... & 6 & +++ & - & - & - & ++++ & $++t+$ & $+t+t$ & $++t+$ \\
\hline Type C.. & 8 & $+t+t$ & ++++ & - & - & ++++ & $++t+$ & $++t+$ & $++t+$ \\
\hline Type D... & 1 & ++++ & +++ & ++ & + & $+++t$ & ++++ & ++++ & ++++ \\
\hline Type E... & 1 & + & ++ & $++t$ & +++ & $+t+t$ & $++t+$ & $+t+t$ & ++++ \\
\hline Type F... & 1 & - & + & + & + & + & + & + & + \\
\hline \multicolumn{10}{|l|}{ A. cloacae: } \\
\hline Type A. & 22 & ++++ & ++++ & $+++t$ & ++++ & ++++ & ++++ & +++ & ++++ \\
\hline Type B. . & 1 & ++++ & ++++ & - & - & ++++ & ++++ & ++++ & ++++ \\
\hline Type C...... & 1 & $+t+t$ & - & - & - & $++t+$ & ++++ & $+t+$ & $+t+t$ \\
\hline Type D..... & 1 & - & ++ & +++ & ++++ & + & ++ & ++ & ++ \\
\hline
\end{tabular}

* Shaken on machine to afford complete aeration.

$\dagger$ In anaerobe jars with atmosphere of nitrogen.

¥ Modified Barritt reagent.

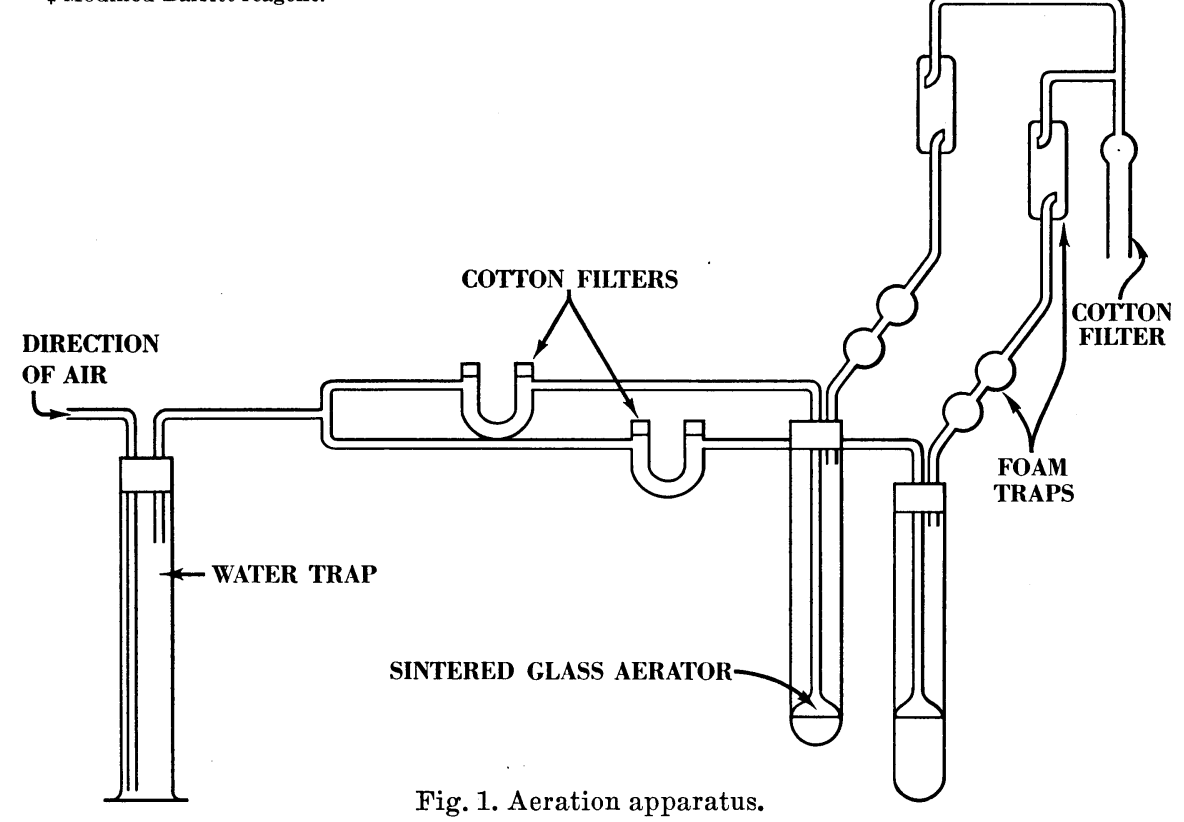

in figure 1. In experiments with this apparatus it was possible to aerate the inoculated medium by compressed air so that all or any desired portion of the medium was continuously and vigorously aerated. Those cultures of $A$. aerogenes and $A$. cloacae that showed negative or weak Voges-Proskauer re- 


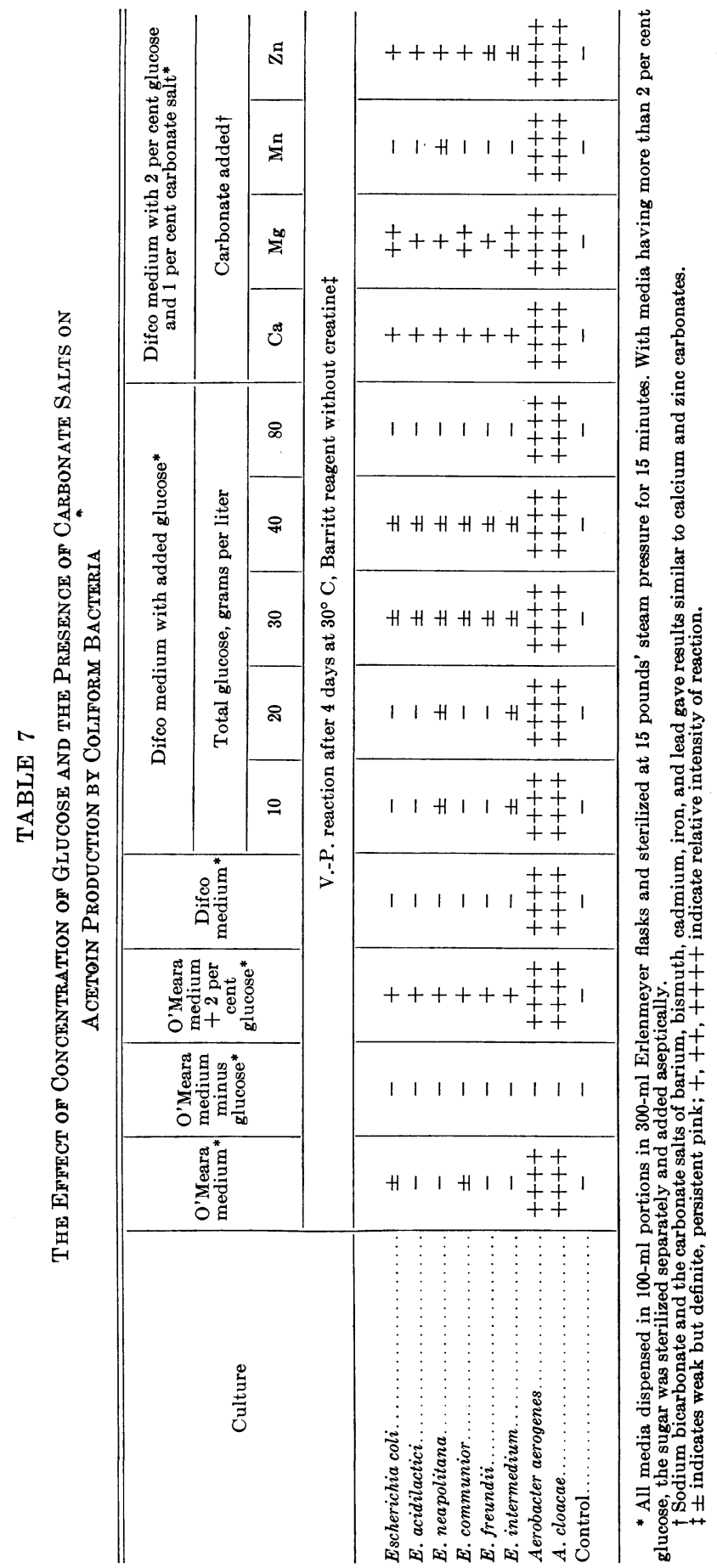


actions when continuously and completely aerated by shaking showed negative reactions when completely aerated with this apparatus. These same cultures showed strongly positive reactions when only partially aerated. Other cultures whose reaction was not affected by aeration by shaking were not influenced by vigorous and complete aeration with this apparatus.

Although complete explanation of the effect of aeration on acetoin production must await final quantitative studies, it is believed that the striking effect of aeration on some cultures and not others is the result of their differences in ability to decompose acetoin. It is well known that growing cultures of coliform bacteria decompose acetoin, as has been shown by Paine (1927), Williams and Morrow (1928), and Tittsler (1938), although it is not clear whether decomposition was effected under aerobic or anaerobic conditions. However, more recently Stanier and Fratkin (1944) have shown that acetoin is oxidized by cell suspensions of one strain of $A$. aerogenes. (These observations should not obscure the fact that aerobic conditions are absolutely necessary for the development of the color reaction of the chemical test for acetoin.)

\section{FACTORS AFFECTING ACETOIN PRODUCTION BY SPECIES OF ESCHERICHIA}

Some confusion exists concerning the ability of Escherichia coli and related species to produce acetoin as indicated by positive Voges-Proskauer reactions. A few (O'Meara, 1931; Reynolds and Werkman, 1937; Kluyver and Molt, 1939 ; and Sakaguchi and Tada, 1940) have demonstrated the production of positive Voges-Proskauer reactions by species of Escherichia, but an overwhelming majority of others have not been so successful.

A study of the literature reveals that workers who demonstrated acetoin production by Escherichia coli and related species used media significantly different from those prescribed as "standard" by the American Public Health Association (1936) and the Ministry of Health (1939). O'Meara (1931) used a synthetic medium which contained 1 per cent sodium fumarate in addition to the customary 0.5 per cent glucose. Other media used successfully for demonstration of acetoin production (positive Voges-Proskauer reactions) by species of Escherichia commonly contained four to eight times the recommended concentration of glucose and from 1 to 2 per cent of sodium bicarbonate or calcium carbonate in addition to other salts not specified as constituents of the standard medium.

It was realized that the composition of the medium might have as marked an effect on the production of positive Voges-Proskauer reactions by species of Escherichia as do the constituents of the medium on hydrogen sulfide production by these bacteria, as previously shown by Vaughn and Levine (1936). Therefore experiments were conducted to determine the effects of concentration of glucose and the use of several insoluble carbonate salts on the production of acetoin by cultures of Escherichia. Results are shown in table 7 .

The concentration of glucose, the presence of various carbonate salts and fumarate (O'Meara media) do have an effect on the ability of species of Escherichia to produce positive Voges-Proskauer reactions. Forced aeration of the growing cultures was not necessary in order to demonstrate positive 
Voges-Proskauer reactions by the test cultures, although it was so specified by Reynolds and Werkman (1937), and Kluyver and Molt (1939).

Since the constituents of the standard medium do not include carbonate salts or fumarate and the glucose concentration is specified as 5 grams per liter, it is quite apparent that the conflicting views concerning the production of positive or negative Voges-Proskauer reactions by Escherichia cultures result primarily from variations from the "standard" both in composition and concentration of constituents of the medium used by those observing positive Voges-Proskauer reactions with Escherichia cultures.

\section{DISCUSSION}

It is evident that the genera Escherichia and Aerobacter are more closely related than once realized because it is true that $\boldsymbol{E}$. coli and related species do produce acetoin (positive Voges-Proskauer reactions) in certain culture media. It is equally true that cultures of Aerobacter fail to produce acetoin in culture media under certain conditions. However, it is apparent from the data presented here and elsewhere that the concentration of acetoin produced by cultures of Escherichia is small and related in some manner to the amount of glucose and the presence of other compounds, as carbonates and fumarate in the medium. Furthermore, if "standard" media are used, the amount of acetoin produced by species of Escherichia generally is not detectable qualitatively, even with the very sensitive $a$-naphthol Voges-Proskauer reagents, without first subjecting the medium to chemical treatment and distillation.

Therefore, the demonstration that members of the genus Escherichia do produce acetoin under certain conditions does not detract from the value of the Voges-Proskauer test if performed under standardized conditions.

A similar situation exists with respect to the ability of coliform bacteria to produce hydrogen sulfide. As shown by Vaughn and Levine (1936), the majority of the coliform bacteria produce $\mathrm{H}_{2} \mathrm{~S}$ from proteose peptone (Difco) in a liquid medium. Yet if the medium contains 1.5 per cent agar in addition to proteose peptone and ferric eitrate (Levine, Vaughn et al., 1932), only cultures of Escherichia freundii produce positive $\mathrm{H}_{2} \mathrm{~S}$, reactions and so the medium can be used for differential purposes.

\section{SUMMARY AND RECOMMENDATIONS}

The results described here have shown that the reagents used for determining the Voges-Proskauer test vary widely in sensitivity and speed of reaction; that the $\mathrm{pH}$ of the medium, if controlled by buffers, does materially influence the ability of cultures of Aerobacter to produce acetoin ; that aeration hinders rather than favors acetoin production by cultures of $A$. aerogenes, whereas aerobic or anaerobic conditions have little effect on acetoin production by the majority of the cultures of $A$. cloacae; and finally, that the concentration of constituents and the composition of the medium markedly influence the ability of cultures to produce positive Voges-Proskauer reactions.

As a result of these investigations and other knowledge which has accumulated in the literature, the following recommendations are made for determining the Voges-Proskauer reaction of coliform bacteria : 
1. The media for determining the Voges-Proskauer reaction should be prepared and used as specified by the American Public Health Association.

2. The a-naphthol, creatine, $\mathrm{KOH}$ solution-a modification of the Barritt reagents made by the authors-is recommended for determining the VogesProskauer reaction.

3. The inoculated medium should be incubated at $30^{\circ} \mathrm{C}$.

4. Excessive aeration of the growing cultures must be avoided.

5. Daily tests for acetoin production must be made. Although the majority of Aerobacter cultures produce positive Voges-Proskauer reactions after 1 day of incubation, some cultures give positive Voges-Proskauer reactions only after 2 days of incubation and others show positive reactions only on the third or fourth day of incubation. Because of this it is advantageous to use $1 \mathrm{ml}$ of culture for conducting the Voges-Proskauer test. 


\section{LITERATURE CITED}

American Public Health Assoctation.

1936. Standard methods for the examination of water and sewage. 8th ed. xiv $+309 \mathrm{p}$. American Public Health Association, New York, N.Y.

BANERJEA, $R$. 1944. Some observations on Voges-Proskauer test. Indian Jour. Med. Res. 32:15-18.

BARRITT, MAXWELL M.

1936. The intensification of the Voges-Proskauer reaction by the addition of a-napthol. Jour. Path. and Bact. 42:441-54.

BATTY-SMITH, C. G.

1941. The detection of acetyl-methyl-carbinol in bacterial cultures. Jour. Hyg. 41:521-29.

KluYver, A. J., and E. L. MolT.

1939. On the production of acetylmethylearbinol by Bacterium coli. K. Nederland Akad. van Wetensch. Proc., 42:118-24.

Leifson, Einar.

1932. An improved reagent for the acetyl-methyl-carbinol test. Jour. Bact. 23:353-54.

Levine, Max, S. S. EPSTEIN, and R. H. VAUGhN.

1934. Differential reactions in the colon group of bacteria. Amer. Jour. Pub. Health $24: 505-10$.

Levine, Max, Reese Vaughn, S. S. Epstein, and D. Q. Anderson.

1932. Some differential reactions in the colon group of bacteria. Soc. Exp. Biol. and Med. Proc. 29:1022-24.

Mickelson, Milo, and C. H. Werkman.

1938. Influence of $\mathrm{pH}$ on the dissimilation of glucose by Aerobacter indologenes. Jour. Bact. 36:67-76.

MINISTRX OF HEALTH.

1939. The bacteriological examination of water supplies. [Gt. Brit.] Min. Health Repts. Pub. Health and Med. Subjs. 71:1-59. Rev. ed.

O'MeARA, R. A. Q.

1931. A simple, delicate and rapid method of detecting the formation of acetyl-methylcarbinol by bacteria fermenting carbohydrate. Jour. Path. and Bact. 34:401-6.

PaINe, F. S.

1927. The destruction of acetyl-methyl-carbinol by members of the colon aerogenes group. Jour. Bact. 13:269-74.

REYNOLDS, H., and C. H. WerKMAN.

1937. Carboligatic activity of Escherichia coli. Arch. f. Mikrobiol. 8:149-52.

SAKaguChI, Kinichiro, and SeIzi TADA.

1940. On the formation of succinic acid by Bacterium succinicum nov. sp. Zentbl. f. Bakt. [etc.] Abt. II, 101:341-54.

Silverman, M., and C. H. WERKMAN.

1941. The formation of acetylmethylcarbinol from pyruvic acid by a bacterial enzyme preparation. Jour. Biol. Chem. 138:35-48.

Smith, Nathan R., Ruth E. Gordon, and Francis E. Clark.

1946. Aerobic mesophilic spore-forming bacteria. U. S. Dept. Agr. Misc. Pub. 559:1-112.

Stanier, R. Y., and Sybil B. Fratkin.

1944. Studies on the bacterial oxidation of 2,3-butanediol and related compounds. Canad. Jour. Res. B $22: 140-53$.

TITTSLER, RALPH P.

1938. The fermentation of acetyl-methyl-carbinol by the Escherichia-Aerobacter group and its significance in the Voges-Proskauer reaction. Jour. Bact. 35:157-62.

VAUghN, REESE, and MAX Levine.

1936. Hydrogen sulfide production as a differential test in the colon group. Jour. Bact. $32: 65-73$.

WERKMAN, C. H.

1930. An improved technic for the Voges-Proskauer test. Jour. Bact. 20:121-25.

Williams, O. B., and Marie B. Morrow.

1928. The bacterial destruction of acetyl-methyl-carbinol. Jour. Bact. 16:43-48.

$4 m-8,48$ (A8064) 
The journal Hilgardia is published at irregular intervals, in volumes of about 600 pages. The number of issues per volume varies.

Subscriptions are not sold. The periodical is sent as published only to libraries, or to institutions in foreign countries having publications to offer in exchange.

You may obtain a single copy of any issue free, as long as the supply lasts; please request by volume and issue number from:

$$
\begin{aligned}
& \text { Publications Office } \\
& \text { College of Agriculture } \\
& \text { Berkeley 4, California }
\end{aligned}
$$

The limit to nonresidents of California is 10 separate issues on a single order. A list of the issues still available will be sent on request. 


$$
\text { (2) }
$$

